J. Japan. Soc. Hort. Sci. 54(3):364-370. 1985.

\title{
Germination Behaviour of Seeds as Affected by Different Temperatures in Some Species of Brassica ${ }^{1}$
}

\author{
Satoru Tokumasu, Izumi Kanada and Masahiro Kato \\ College of Agriculture, Ehime University, Matsuyama 790
}

\begin{abstract}
Summary
Germination tests of seeds were carricd out at 5 different temperatures, i. e., 5 , $15,25,35$, and $45 \mathrm{C}$, using 11 different crops of Brassica. Germination was examined every two hours and, afterwards, every 12 or 24 hours. In every crop, seeds began to germinate earliest at $35^{\circ} \mathrm{C}$ and latest at $5 \mathrm{C}$. The start of germination became later in the decreasing order of temperature from 35 to $5^{\circ} \mathrm{C}$. Seeds at $45^{\prime} \mathrm{C}$ began to germinate as carly as those at $35 \mathrm{C}$ in many crops, but in some crops the start of germination was much dclayed. Mean germination period was shortest at $35 \mathrm{C}$, and shorter at $25^{\circ} \mathrm{C}$ in every crop. These temperatures were followed by cither 15 or $45 \mathrm{C}$ with respect to mean length of period. The longest period was needed for germination at $5 \mathrm{C}$. As for germination percentage, seeds at 35,25 and $15 \mathrm{C}$ showed more than $85 \%$ in all of the crops examined. At $4 \overline{5}$ or $5 \%$, low percentages of germination were frequently observed. Differences among crops were observed at these tempcratures: some crops showed bad germination at $45 \mathrm{C}$, and some at $5 \mathrm{C}$, and others at both $4 \overline{5}$ and $5 \mathrm{C}$. The response of non-dormant seeds was different from that of dormant seeds in terms of germination temperature. Optimum temperatures for germination of non-dormant seeds were higher than those of partially dormant seeds.
\end{abstract}

\section{Introduction}

It is well known that there are so-called 'cardinal temperatures'--minimum, optimum and maximum - when sceds germinate. In Brassica species, germination temperature has not been studied systematically, though some reports are found $(2,3,11,12)$. In particular, there are no reports dealing with the process of germination behaviour of secds with the lapse of time. The present study was conducted to examine the germination of seeds at different temperatures in various crops of Brassica.

\section{Materials and Methods}

Materials in the present study were seeds of eleven crops in Brassica (Table 1). Potherb mustard, rape and leaf mustard had been maintained at Ehime University and sometimes used in the studies of seed dormancy $(4,5,6,7,8,9,10)$. Red cabbage was kindly

\footnotetext{
1 Reccived for publication March 11, $198 \overline{5}$
}

supplied by Dr.C. (jomez-Campo, Madrid, Spain. The other crops were obtained from some commercial seed firms.

Germination tests were begun at 0 a.m. on November 23, 1980, in Chinese cabbage, red cabbage, rape and leaf mustard, and on January 27,1981 , in other crops. Petri-dishes, in which sceds were laid on two sheets of blotting paper moistened with water, were placed in the thermostat. The tests were conducted at five different temperatures, i. e., $5,15,25,35$ and $45 \mathrm{C}$. In every crop, 200 seeds were employed at each temperature. Radicle protrusion through the seed coat was regarded as germination. The number of germinated seeds was recorded every two hours until 60 hours after sowing. After that, counting of germinated seeds was done at 12 or 24 hour intervals until about 300 hours, and water was sometimes added to the petri-dishes during this period. 
Table 1. Materials used in the germination test of seeds.

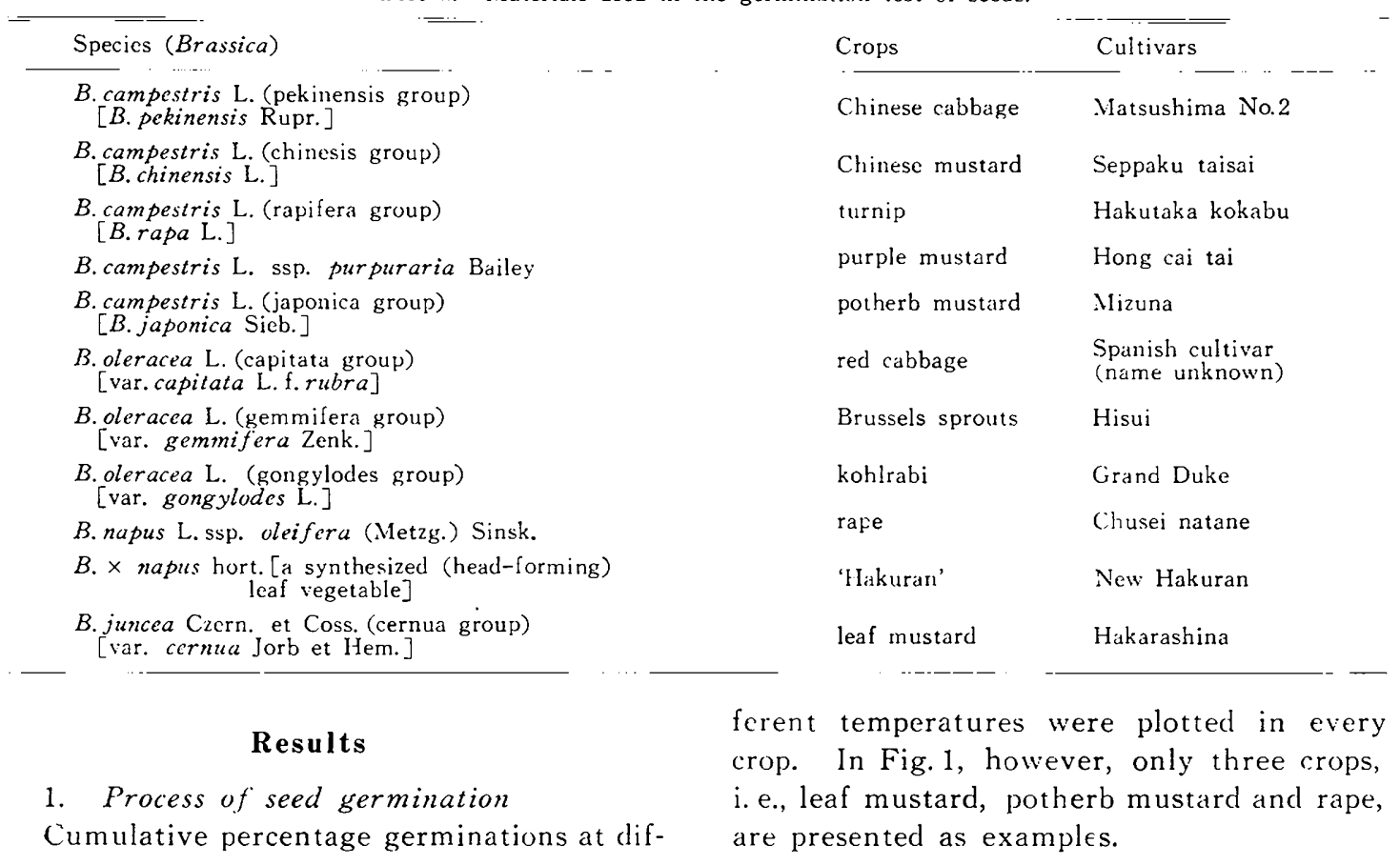
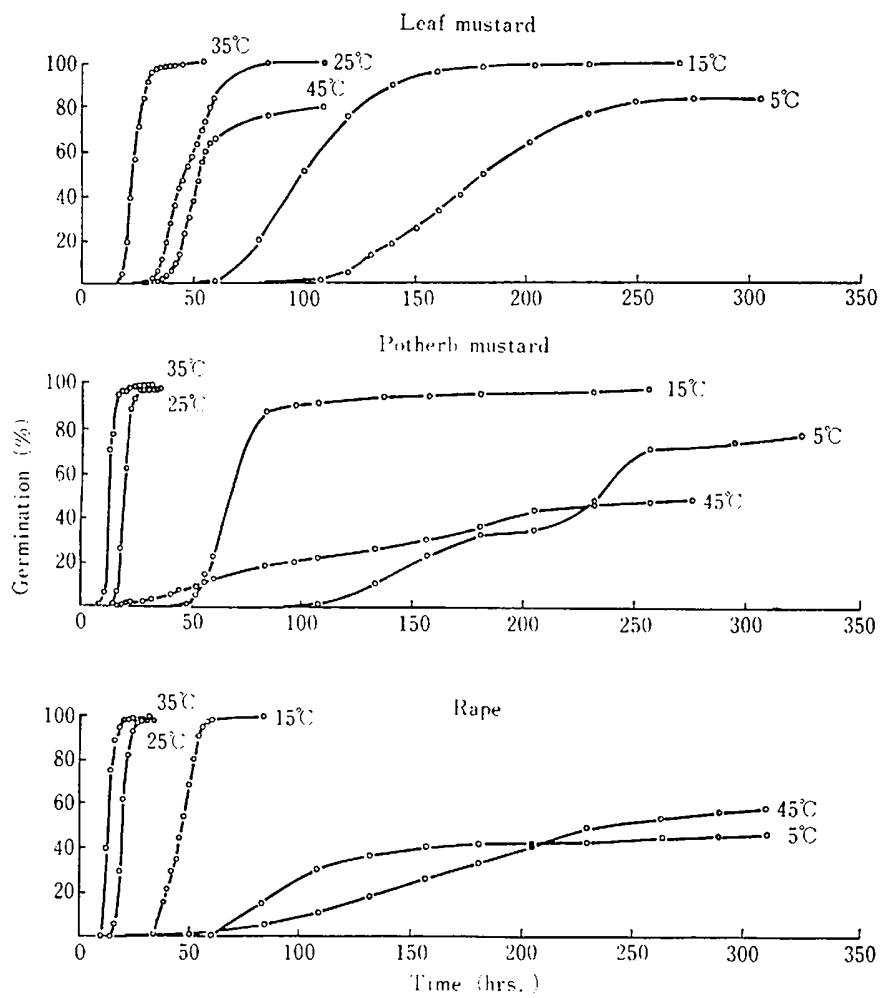

Fig. 1 Progress of cumulative percentage germination of seeds in leaf mustard, potherb mustard and rape. 


\section{1) Leaf mustard}

In leaf mustard, seeds at $35^{\circ} \mathrm{C}$ began to germinate at 14 hours after sowing, and, after that, the germination percentage increased rapidly and reached $99 \%$ at about 50 hours. Seeds at $25^{\circ} \mathrm{C}$ began to germinate at 18 hours. The germination curve of this seed lot was not so steep as that at $35^{\circ} \mathrm{C}$. The germination percentage reached $100 \%$ at about 100 hours. The time when seeds at $45^{\circ} \mathrm{C}$ began to germinate was 30 hours after sowing. They showed a maximum germination $(79 \%)$ at 110 hours. Thercafter, they did not germinate any more. The start of seed germination at $15^{\circ} \mathrm{C}$ was delayed, being at 54 hours after sowing. It took 270 hours for seeds to attain $98 \%$ germination. The germination of seeds at $5^{\circ} \mathrm{C}$ was much later and slower. They began to germinate at 92 hours and the final germination percentage was $83 \%$ at the end of the experiment.

2) Potherb mustard

In potherb mustard, the germination of seeds at $35^{\circ} \mathrm{C}$ began much earlier than that of leaf mustard at the same temperature. That is, they began to germinate at 8 hours after sowing. The germination curve rose very rapidly in a short time, and almost all seeds finished their germination at 24 hours after sowing. In seeds at $25 \%$, which began to germinate at 12 hours, the germination curve had a steep slope similar to that at 35 "C. The germination percentage reached 98 $\%$ at about 30 hours. Though seeds at $45^{\circ} \mathrm{C}$ began to germinate as early as those at $35^{\circ} \mathrm{C}$, their germination was generally slow. Even after 300 hours the germination percentage remained $49 \%$. The germination curve of sceds at $15^{\circ} \mathrm{C}$ rose to a certain high level in a comparatively short time, after the germination began at 46 hours. The germination percentage reached $90 \%$ at 90 hours, though 260 hours were required for $98 \%$ germination. The germination of seeds at $5^{\circ} \mathrm{C}$ was late and slow. The beginning time of germination was 96 hours after sowing, and the final germination percentage was $78 \%$.

3) Rape

In rape, seeds at $35 \mathrm{C}$ began to germinate at 10 hours after sowing. The germination curve of this seed lot closely resembled that of potherb mustard at the same temperature, showing a very steep slope. In the case of seeds at $25^{\circ} \mathrm{C}$, germination began at 14 hours after sowing. They presented a germination curve similar to that of potherb mustard at $25^{\circ} \mathrm{C}$. At $45^{\circ} \mathrm{C}$, the time when seeds began to germinate was as early as 12 hours after sowing. However, owing to their slow germination, the germination percentage remained $59 \%$ at the end of the experiment. Seeds at $15^{\circ} \mathrm{C}$ began to germinate at 32 hours after sowing and reached $100 \%$ germination at 80 hours. The germination of seeds at $5^{\circ} \mathrm{C}$ was late and slow. They began to germinate at 60 hours after sowing, and the final germination percentage was only $46 \%$.

4) Other crops

In the crops other than the above-mentioned three, there were more or less variations in the pattern of germination curves. If they are roughly grouped according to the similarity of their patterns, the following can be made. (1) leaf mustard type : Chinese cabbage and turnip ; (2) potherb mustard type : Chinese mustard, purple mustard, red cabbage, Brussels sprouts and kohlrabi ; (3) rape type: 'Hakuran'.

2. Earliness or lateness of the start of germination

Table 2 shows the time from sowing to the start of germination at different temperatures

Table 2. Time from sowing to the start of germination in Brassica seeds at different temperatures.

\begin{tabular}{|c|c|c|c|c|c|}
\hline \multirow{2}{*}{ Crops } & \multicolumn{5}{|c|}{ Germination temperature } \\
\hline & $45^{\circ} \mathrm{C}$ & $35^{\circ} \mathrm{C}$ & $25^{\circ} \mathrm{C}$ & $15^{\circ} \mathrm{C}$ & $5^{\circ} \mathrm{C}$ \\
\hline & hrs. & hrs. & hrs. & hrs. & hrs. \\
\hline Chinese cabbage & 8 & 8 & 16 & 48 & 82 \\
\hline Chinese mustard & 8 & 8 & 12 & 30 & 92 \\
\hline Turnip & 10 & 8 & 10 & 48 & 70 \\
\hline Purple mustard & 10 & 8 & 8 & 22 & 54 \\
\hline Potherb mustard & 8 & 8 & 12 & 46 & 96 \\
\hline Red cabbage & 26 & 12 & 14 & 52 & 84 \\
\hline Brussels sprouts & 10 & 14 & 18 & 38 & 98 \\
\hline Kohlrabi & 8 & 8 & 20 & 54 & 134 \\
\hline Rape & 12 & 10 & 14 & 32 & 60 \\
\hline 'Hakuran' & 8 & 8 & 22 & 38 & 134 \\
\hline Leaf mustard & 30 & 14 & 18 & 54 & 92 \\
\hline Mean & 13 & 10 & 15 & 42 & 91 \\
\hline
\end{tabular}


with respect to 11 different crops. In every crop, except Brussels sprouts, the earliest germination was found at $35^{\circ} \mathrm{C}$. Seeds at $35^{\circ} \mathrm{C}$ began to germinate at 8 to 14 hours after sowing. On the other hand, the latest germination was observed at $5^{\circ} \mathrm{C}$ in all crops, among which there was a wide variation in the starting time of germination ranging from 54 to 134 hours. As far as the temperature range between 35 and $5^{\circ} \mathrm{C}$ is concerned, germination became later and its variation became wider in the decreasing order of temperature : $35,25,15$ and $5^{\circ} \mathrm{C}$. As a whole, seeds at $45^{\circ} \mathrm{C}$ began to germinate as early as those at $35^{\circ} \mathrm{C}$. In Brussels sprouts seeds at $45^{\circ} \mathrm{C}$ began to germinate earlier than at $35^{\circ} \mathrm{C}$. In red cabbage and leaf mustard, however, germination at $45^{\circ} \mathrm{C}$ was much later than at $25^{\circ} \mathrm{C}$.

\section{Mean germination period}

Table 3 presents average time required for germination (mean germination period). In every crop, mean germination period was shortest at $35^{\circ} \mathrm{C}$, and shorter at $25^{\circ} \mathrm{C}$. Seeds at these temperatures were followed by those at $15^{\circ} \mathrm{C}$ in some crops or at $45^{\circ} \mathrm{C}$ in others. The longest period was needed for germination at $5^{\circ} \mathrm{C}$. In Brussels sprouts and kohlrabi, however, seeds at $45^{\circ} \mathrm{C}$ had the same length of period as at $35^{\circ} \mathrm{C}$, and in rape germination period was longest at $45^{\circ} \mathrm{C}$. In conclusion, germination was rapid at the temperature of 35 and $25^{\circ} \mathrm{C}$ in every crop. This

Table 3. Average time required for germination.

\begin{tabular}{lcclcc}
\hline & \multicolumn{5}{c}{ Germination temperature } \\
\cline { 2 - 6 } & $45^{\circ} \mathrm{C}$ & $35^{\circ} \mathrm{C}$ & $25^{\circ} \mathrm{C}$ & $15^{\circ} \mathrm{C}$ & $5^{\circ} \mathrm{C}$ \\
\hline & hrs. & hrs. & hrs. & hrs. & hrs. \\
Chinese cabbage & 44 & 17 & 26 & 109 & 196 \\
Chinese mustard & 67 & 17 & 25 & 49 & 124 \\
Turnip & 41 & 13 & 22 & 96 & 175 \\
Purple mustard & 92 & 15 & 20 & 47 & 92 \\
Potherb mustard & 127 & 13 & 20 & 83 & 211 \\
Red cabbage & 84 & 20 & 27 & 87 & 180 \\
Brussels sprouts & 47 & 48 & 50 & 88 & 148 \\
Kohlrabi & 45 & 46 & 46 & 104 & 223 \\
Rape & 175 & 14 & 21 & 47 & 124 \\
'Hakuran' & 84 & 38 & 48 & 105 & 241 \\
Leaf mustard & 56 & 25 & 52 & 114 & 176 \\
\hline Mean & 78 & 24 & 33 & 85 & 172 \\
\hline
\end{tabular}

rapidness of germination extended to either higher temperature range $\left(45^{\circ} \mathrm{C}\right)$ or to lower temperature one $\left(15^{\circ} \mathrm{C}\right)$ according to crops. About half of the crops showed the extention to the higher temperature, and the rest half to the lower one.

\section{Germination Percentage}

Germination percentage at the end of the experiment differed according to crops (Table 4). In all of the crops, seeds at 35,25 and 15 ${ }^{\circ} \mathrm{C}$ showed good germination (more than 85 $\%$ ), whereas low percentages of germination were frequently found at 45 or $5^{\circ} \mathrm{C}$. Each crop could be classified into one of the following three groups in terms of the temperatures at which low percentages, say, less than 85 $\%$, were observed. (1) Crops showing bad germination at $45^{\circ} \mathrm{C}$ only were Chinese mustard, purple mustard, red cabbage and Brusels sprouts, (2) those at $5{ }^{\circ} \mathrm{C}$ only were $\mathrm{Chi}$ nese cabbage and turnip, and (3) those at both 45 and $5^{\circ} \mathrm{C}$ were potherb mustard, kohlrabi, rape, 'Hakuran' and leaf mustard. Average percentages of germination in the whole crops were $98 \%$ at 35 and $25^{\circ} \mathrm{C}, 96 \%$ at $15^{\circ} \mathrm{C}, 77 \%$ at $5^{\circ} \mathrm{C}$, and $50 \%$ at $45^{\circ} \mathrm{C}$.

Table 4. Percentage germination of Brassica seeds at different temperatures.

\begin{tabular}{|c|c|c|c|c|c|}
\hline \multirow{2}{*}{ Crops } & \multicolumn{5}{|c|}{ Germination temperature } \\
\hline & $45^{\circ} \mathrm{C}$ & $35^{\circ} \mathrm{C}$ & $25^{\circ} \mathrm{C}$ & $15^{\circ} \mathrm{C}$ & $5^{\circ} \mathrm{C}$ \\
\hline & $\%$ & $\%$ & $\%$ & $\%$ & $\%$ \\
\hline Chinese cabbage & 95 & 100 & 97 & 87 & 83 \\
\hline Chinese mustard & 19 & 97 & 96 & 99 & 91 \\
\hline Turnip & 95 & 97 & 99 & 85 & 50 \\
\hline Purple mustard & 7 & 99 & 98 & 100 & 98 \\
\hline Potherb mustard & 49 & 99 & 98 & 98 & 78 \\
\hline Red cabbage & 82 & 100 & 99 & 100 & 100 \\
\hline Brussels sprouts & 3 & 98 & 97 & 97 & 92 \\
\hline Kohlrabi & 12 & 97 & 98 & 96 & 76 \\
\hline Rape & 59 & 100 & 99 & 100 & 46 \\
\hline 'Hakuran' & 47 & 89 & 96 & 93 & 54 \\
\hline Leaf mustard & 79 & 99 & 100 & 98 & 83 \\
\hline Mean & 50 & 98 & 98 & 96 & 77 \\
\hline
\end{tabular}

\section{Discussion}

Kotowski (3) carried out the germination tests of various vegetable seeds at different temperatures and found that the highest number of seedlings was obtained at $8^{\circ} \mathrm{C}$ for 
ci bage, but the number of seedlings was eo $t 1$ within the interval between 8 and $18^{\circ} \mathrm{C}$ fo cauliflower. According to Toole and Tor : (11), the temperatures at which non' rrm. it seeds showed germination of more than $\%$ were 15 to $25 \mathrm{C}$ in Argentine bird rape (_ assica campestris), and 10 to $30 \mathrm{C}$ in Indian bird rape (B.campestris) and leaf mustard ( $B$. juncea). In B. nigra, a comparatively high percentage of germination, i. e., about $80 \%$, was found at temperatures between 10 and $25^{\circ} \mathrm{C}$. Inagawa and Miyase (2) found that optimal temperatures for seed germination were 15 to $25^{\circ} \mathrm{C}$ in turnip, 15 to 35 ${ }^{\circ} \mathrm{C}$ in Chinese cabbage, and 15 to $30^{\circ} \mathrm{C}$ in cabbage. Toole et al. (12) reported optimal temperatures for germination to be in the region of 15 to $25^{\circ} \mathrm{C}$ in $B$. juncea seeds. Since 'optimal' temperatures are usually indicated by the temperatures at which seeds can germinate in large numbers, it may be necessary to examine the range of temperatures at which more than $90 \%$ of seeds could germinate in each crop of the present experiment. Such ranges of temperatures were 5 to $35^{\circ} \mathrm{C}$ in Chinese mustard, purple mustard, red cabbage, and Brussels sprouts, 15 to $35 \mathrm{C}$ in potherb mustard, kohlrabi, rape, 'Hakuran', and leaf mustard, and 25 to $45^{\circ} \mathrm{C}$ in Chinese cabbage and turnip (Table 4). From the above data obtained by the different authors as well as by the present experiment, it is inferred that optimal temperature ranges differ more or less with cultivars or strains even in the same species. Further, no direct relation could be noticed between genomic constitutions of specics and optimal temperature ranges. For instance, Chinese cabbage, Chinese mustard, turnip, purple mustard, and potherb mustard are classified in to the same A-genomic species $(n=10)$, but their optimal temperature ranges are not always the same. Such differences may be caused not only by genetic traits of seeds but also by environmental backgrounds in which seeds were harvested. As a whole, however, it may be concluded that in Brassica species, on an average, germination percentages are high at temperatures between 15 and $35^{\circ} \mathrm{C}$, low at $5 \mathrm{C}$, and very low at $45^{\circ} \mathrm{C}$
(Table 4).

As for the start and duration of seed germination, a marked feature is noticed within the temperature range between $35 \mathrm{C}$ and $5^{\circ} \mathrm{C}$ (Tables 2 and 3 ). In every crop the temperature at which seeds germinated earliest and fastest was $35^{\circ} \mathrm{C}$. Then, the start of germination became later and the time required for germination becamelonger as temperatures declined from 35 to $5: \mathrm{C}$. Finally, seeds at $5^{\circ} \mathrm{C}$ showed the latest and slowest germination. In conclusion, the start and duration of seed germination are inversely proportional to temperatures, as far as the temperature range between 35 and $5 \mathrm{C}$ is concerned. This tendency was the same in all the crops examined here and also in cabbage and cauliflower treated by Kotowski (3). However, seeds subjected to $45 \mathrm{C}$ were differently affected. In many crops seeds at $45^{\circ} \mathrm{C}$ began to germinate as early as those at $35 \mathrm{C}$, but in some crops the start of germination was much delayed (Table 2). Further, at $45^{\circ} \mathrm{C}$ the mean germination period of seeds was more variable than the starting time of germination. In many crops the length of mean germination period at $45 \mathrm{C}$ fell within that of the period found between 25 and $5 \mathrm{C}$ (Table 3 ), but in some crops much shorter or much longer period was needed for germination. Roughly speaking, the effect of very high temperature such as $45 \mathrm{C}$ is promotive for the start of germination, and inhibitive for the duration and percentage of germination. Therefore, it seems that each of germination factors, i. e., the start, dura tion and percentage of germination, may be separately affected by the temperature.

Curves of cumulative germination in sceds whose germination was rapid were typically sigmoid as shown at 35 and $25^{\circ} \mathrm{C}$ (Fig. 1 ).

However, as the germination period became longer, curves became stretched and sometimes quasi-linear as found at 15,45 or $5 \mathrm{C}$. Edwards (1) stated that soybean seeds at different germination temperatures showed all sigmoid curves of similar type and the only difference among temperatures was starting points at which germination began. The temperature range in his experiment, how- 
ever, was between 24.5 and $40 \mathrm{C}$. If temperatures were extended beyond this range, sigmoid curves would be deformed and stretched as seen in the present experiment. In Brassica, the steepness of slope of curves is related to the duration of germination and neither necessarily to the starting points nor to the percentage of germination.

The germination response of seeds to different temperatures as described above was that of seeds whose dormancy was completely removed, as evidenced by $96-100 \%$ germination at favorable temperatures (Table 4). This response is different from that of dormant seeds. Tokumasu et al. (9) demonstrated the germination response of seeds taken from 0 to 12 weeks after harvest in three crops: leaf mustard, potherb mustard and rape. These seeds were in the course of removal of dormancy, that is, so-called afterripening. In leaf mustard, germination began at $15 \mathrm{C}$, which was followed by $25,35,5$ and $45 \mathrm{C}$ in sequence. In potherb mustard, seeds germinated simultaneously at 15,25 and $35^{\circ} \mathrm{C}$, and later at 5 and $45 \mathrm{C}$. In rape, the earliest germination was found at $5 \mathrm{C}$, but seeds in this lot were surpassed by those at 15 and $25 \mathrm{C}$ after a week. Later germination was shown at $35 \mathrm{C}$ and latest at $45 \mathrm{C}$. These results support the opinion of Vegis (13) that freshly harvested seeds bcgin to germinate only at a certain comparatively low temperature and, with the advance of after-ripening, they widen temperature ranges at which they can germinate. This phenomenon was also shown in B. campestris and B. juncea (11). In short, 15 to $25 \mathrm{C}$ were favorable for the germination of partially dormant seeds in Brassica, and the most favorable was probably $15^{\circ} \mathrm{C}$ or a little above. These temperatures are low as compared with favorable temperatures $\left(25 \sim 35^{\circ} \mathrm{C}\right)$ proved in the present experiment for germination of non-dormant seeds.

\section{Literature cited}

1. EDWARDS, S. T. I. 1934. Relations of germinating soybeans to temperature and length of incubation time. PI. Physiol. Lancaster $9: 1-30$.

2. INAGAW , T. and I. MiYASE. 1943. Minimum, optimum and maximum germination temperatures in vegetable seeds (In Japanese). Agric. \& Hort., Tokyo 18: 763.

3. KoTOWSKI, F. 1927. Temperature relations to germination of vegetable seeds. Proc. Amer. Soc. Hort. Sci. $23: 176-184$.

4. Tokumasu, S. 1970. Prolongation of seed dormancy by dry storage in Brassica japonica Sieb. J. Japan. Soc. Hort. Sci. 39 : $169-177$.

5. TOKLMASU, S. 1971. Effect of dry and wet storage upon seed dormancy in cruciferous vegetables. J. Japan. Soc. Hort. Sci. 40 : $23-28$.

6. TOKUMASU, S. 1975. Prolonged dormancy in the seeds preserved in harvested fruits of Brassica vegetables. Scientia Hortic. 3 : $267-273$.

7. TOKUMASU, S. 1977. Seasonal periodicity of the loss of dormancy of imbibed seeds in Brassica vegetables. Scientia Hortic. 6 : $101-106$.

8. TOKUMASU, S., M. KATO and F. YANO. 1975. The dormancy of seed as affected by different humidities during storage in Brassica (In Japanese with English summary). Japan. J. Breed. 25: 197-202.

9. TOKuMASU, S., S. KAMEI and M. KaTO. 1981. Effects of storage humidity and germination temperature on germination percentage of Brassica seeds (In Japanese with English summary). Japan. J. Breed. 31: 109-120.

10. TOKLMASU, S., F. KAKIHARA and M. KATO. 1981. The change of dormancy of seeds stored in desiccators and/or harvested fruits in cruciferous crops (In Japanese with English summary). J. Japan. Soc. Hort. Sci. $50: 208-214$.

11. TOOLE, E. H. and V. K. TOOLE. 1939. Germination of some Brassica types at different temperatures. Proc. int. Seed Test Ass. 11 : $51-56$.

12. TOOLE, E. H., V. K. TOOLE, H. A. BORTHWICK and S. B. HENDRICKS. 1955. Interaction of temperature and light in germination of seeds. Plant Physiol. $30: 473-478$.

13. VEGis, A. 1964. Dormancy in higher plants. Ann. Rev. Plant Physiol. 15 : 185224 . 


\title{
アブラナ属作物種子の発芽に対する温度の影響 \\ 德増 智 - 金时 泉 - 加藤正刕

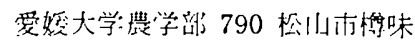

\begin{abstract}
摘 要
フブラナ属作物 11 種颣の程了を用いて， $5 ， 15 ， 25$ ， 35 收び $45^{\circ} \mathrm{C}$ の 5 段階の温度で発芽試娩を行い，活休後

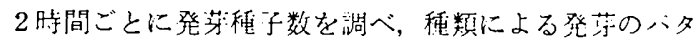

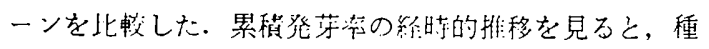
類によってのバターンは巽なるが，洪通した慎们も誌め らせるる.

各作物種子ともに，最も早く発芽を開始し心のは 35 'Cで，次いで $25 ， 15 ， 5^{\circ} \mathrm{C}$ と温度が低下寸るにつれて発 获は掘くなり，また，種類による発芽開姑时撕の变異幅

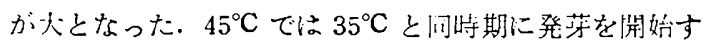
るかまたそれより遅く，稞頪によって筫なった。

だ、さらに，作物の種類により $15^{\circ} \mathrm{C}$ まは $45^{\circ} \mathrm{C}$ が綂 き， $5^{\circ} \mathrm{C}$ はいずれの作物でも発素に最長の㭙間を要し た.

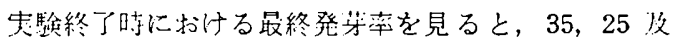

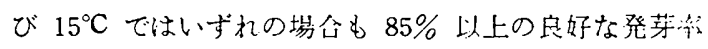
をぶした，その他の温度区では作物の種類により発芽率 か $45^{\circ} \mathrm{C}$ のみで低いもの， $5^{\circ} \mathrm{C}$ のみで低いもの，また $45^{\circ} \mathrm{C}$ 及び $5{ }^{\circ} \mathrm{C}$ の河jで低いものに分けられた。

以上の結果から，休眠の觉醒した種子の最適発讶温度

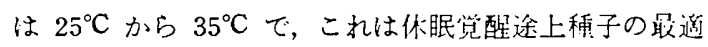
発获温度が $15^{\circ} \mathrm{C}$ 以トであるのに比べて明らかに高い。
\end{abstract}

平均発芽期間は $35^{\circ} \mathrm{C}$ が咠も短く, $25^{\circ} \mathrm{C}$ がこれに次い 